\title{
Integrasi Kearifan Lokal dalam Evaluasi Lahan bagi Budidaya Enbal (Manihot esculenta Crantz) pada Kaki Gunung Ar, Pulau Yut, Maluku Tenggara
}

\author{
Integration of Local Wisdom in Land Evaluation for Enbal Cassava (Manihot esculenta Crantz) \\ Cultivation in the Footslope of Mount Ar, Yut Island, Southeastern Maluku
}

\section{Geogriani Anthonius ${ }^{1}$, Condradus Ufie ${ }^{2, *}$, Simson Liubana ${ }^{2}$}

${ }^{1}$ Program Studi Agroteknologi, Jurusan Budidaya Pertanian, Fakultas Pertanian, Universitas Pattimura, Jln. Ir. M. Putuhena, kampus Unpatti poka Ambon 97233, Indonesia

${ }^{2}$ Jurusan Budidaya Pertanian, Fakultas Pertanian, Universitas Pattimura, Jln. Ir. M. Putuhena, kampus Unpatti poka Ambon 97233, Indonesia

*E-mail Penulis Korespondensi: condradus.ufie@faperta.unpatti.ac.id

\begin{abstract}
Cassava is a food and trade commodity in the Kei Islands, Maluku Province. Various aspects of the cultivation of this crop are determined by traditional knowledge held by farmers from generation to generation. This study aimed to: 1) describe the potential of local wisdom (traditional knowledge) about the land owned by the Ohoi Wasar community in the Kei Islands regarding the suitability of the coastal land management for 'enbal' (bitter cassava) cultivation; 2) integrate local knowledge about land belonging to the Ohoi Wasar indigenous people with FAO land evaluation (modern soil knowledge in land suitability evaluation) for sustainable cultivation of 'enbal' cassava. This research was carried out using a transect-based survey method that was participatory and goal-oriented, which focused on farmers who cultivate 'enbal' cassava and their fields on the coastal land in the footslope of Mount Ar. The results of the study were: 1) there was local-traditional wisdom of the Wasar community that was directly related to 'enbal' cultivation (ethnopedological system); firstly, the wisdom of determining land suitability for 'enbal' cassava cultivation (ie. hadoichr ngametan or black soil = Renzina, and hadoichr vuil or red soil = Cambisol Dystrict); secondly was the wisdom of determining the time/day of land clearing for 'enbal' gardens (slash-and-burn) and the planting time which was started in early May; in addition, there was a supporting wisdom in the diversity or reliance of local foods, namely the habit of harvesting and consuming "boo" with "es`ullaor " at the end of March; 2) when the potential of local knowledge about soils (ethnopedology system) was integrated with the FAO FAO system of land evaluation, it appeared that there was an overlap in the studies of soil fertility, namely both categorizing "black soil" as more fertile (very suitable), and "red soil" as a less fertile" (slightly suitable) soil.
\end{abstract}

Keywords: Ar-Wasar, bitter cassava, 'enbal', land evaluation, local wisdom

\section{ABSTRAK}

Ubi kayu merupakan komoditas pangan dan perdagangan di Kepulauan Kei, Provinsi Maluku. Berbagai aspek budidaya tanaman ini ditentukan oleh pengetahuan tradisional yang dipegang oleh petani secara turun temurun. Penelitian ini bertujuan: 1) menginventarisasi potensi kearifan lokal (pengetahuan tradisional) tentang tanah yang dimiliki masyarakat Ohoi Wasar di Kepulauan Kei terkait kesesuaian pengelolaan lahan pesisir bagi budidaya tanaman enbal (ubi kayu pahit); 2) mengintegrasikan kearifan pengetahuan lokal tentang tanah yang dimiliki masyarakat adat Ohoi Wasar dengan evaluasi lahan FAO (pengetahuan tanah moderen dalam evaluasi kesesuaian lahan) bagi budidaya tanaman enbal yang berkelanjutan. Penelitian dilaksankan dengan metode survey berbasis transek secara partisipatif berorientasi tujuan, yang difokuskan pada petani yang bercocok tanam enbal dan kebunnya pada lahan pesisir kaki Gunung Ar. Hasil penelitian adalah: 1) Ada kearifan lokal-tradisonal dari masyarakat Wasar yang terkait langsung dengan budidaya enbal (sistem etnopedologi); pertama, kearifan penentuan tanah/lahan yang cocok atau sesuai bagi usaha kebun enbal (yakni hadoichr ngametan atau tanah hitam = Renzina, dan hadoichr vuil atau tanah merah =Kambisol Distrik); kedua, kearifan penentuan waktu/hari buka kebun enbal (tebas-bakar) dan waktu tanam di awal Mei; selain itu, terdapat kearifan pendukung dalam keragaman/kemandirian pangan lokal, yakni kebiasaan panen dan konsumsi "boo" bersama "es 'u/laor" pada akhir Maret. 2) Jika potensi kearifan pengetahuan tanah lokal (sistem etnopedologi) diintegrasikan dengan evaluasi lahan sistem FAO, nampak titik temunya (overlap) pada telaahan kesuburan tanah, yakni keduanya mengkategorikan "tanah hitam" sebagai yang lebih subur (sangat sesuai), dan "tanah merah" kurang subur (cukup sesuai).

Kata kunci: Ar-Wasar, enbal, evaluasi lahan, kearifan lokal, ubi kayu pahit

\section{PENDAHULUAN}

Kepulauan Kei (nuhu-tanat evav, dalam bahasa setempat) adalah salah satu gugusan kepulauan yang ada di Kabupaten Maluku Tenggara. Kepulauan ini termasuk Gugus Kepulauan VIII, berdasarkan Peta Gugus pulau dalam 
Rencana Tata Ruang Wilayah (RTRW) Provinsi Maluku. Sesuai namanya, Kei Besar atau pulau Yut merupakan pulau yang luasnya lebih besar daripada Kei Kecil dalam kategori Pulau-Pulau Kecil (Undang-undang No. 27 Tahun 2007) yang rentan, dimana secara umum makanan pokok masyarakatnya adalah ubi kayu (Manihot esculenta Crantz, Euphorbiaceae) atau tanaman enbal (sebutan lokal dari masyarakat Kepulauan Kei).

Ubi kayu merupakan tanaman pangan dan perdagangan (cash crop) (Prihandana et al., 2007). Sebagai tanaman perdagangan, dengan topangan ilmu pengetahuan dan teknologi (iptek) moderen, ubi kayu menghasilkan pati, tepung ubi kayu (MOCAF), pellets, gula cair, etanol, bioenergi (bahan bakar nabati) dan bioplastik, serta sekitar 12-15 produk turunan. Produk-produk ubi kayu dapat menghidupi industri hulu dan hilir skala kecil sampai besar. Fokus kajian ini adalah ubi kayu sebagai tanaman pangan, khususnya di Kepulauan Kei, mengingat masyarakat setempat mengolah ubi kayu pahit (beracun) ini melalui berbagai proses arif (kearifan lokal) menjadi pangan lokal utama yang dikonsumsi turun-temurun dari zaman leluhur hingga kini; mulai dari budidaya hingga olahan lepas panen, termasuk penggunaan sebagai ramuan obat tradisional. Pangan lokal enbal berbasis pengetahuan dan teknologi indigenous ini pun sudah mulai berkembang dengan sentuhan iptek moderen dalam skala sederhana (home industry) baik pengolahan maupun pengemasan yang cenderung berkembang dan bersaing, melalui usaha mikro kecil dan koperasi pada ohoi atau desa pesisir yang ada.

Dengan luas lahan pulau/kepulauan kecil yang terbatas, maka umumnya masyarakat Kei menggunakan lahan yang ada untuk budidaya tanaman enbal ini secara multi-kultur/agroforestri tradisional, dalam arti enbal ditanam di antara tanaman pepohonan berumur panjang (kelapa, mangga, sukun, jambu, kayu besi, pepaya dan lain-lain termasuk pisang). Pilihan jenis tanaman umur panjang atau pepohonan ini tergantung pada kebiasaan multifungsi lokasional (lihat Clarke dan Thaman, 1993; FAO, 1994; Widodo et al., 2018). Jadi, pilihan tanaman pepohonan dalam tradisi polikultur ini sedikit bervariasi dari satu ke lain desa pesisir yang ada. Nampaknya sistem polikultur tradisional ini mirip dengan sistem pertanian kepulauan (oceanic agricultural system where based on root and tree crops) di berbagai kepulauan Pasifik, yang merupakan hasil proses difusi dan adaptasi dari Sahulland atau Sahul Continent-Benua Sahul (Yen, 1995; Bulbeck, 2006).

Begitu pula dengan kondisi di desa/ohoi Wasar, Kecamatan Kei Besar Utara Timur. Umumnya perkebunan rakyat yang ada di sana memiliki luas lahan yang sempit dengan sistem agroforestri tradisional yang khas, dimana satu lahan kebun tidak hanya di tanami tanaman ubi kayu atau enbal (monokultur) saja melainkan ada tanaman-tanaman yang lain, utamanya pepohonan yang tumbuh berdampingan. Selain luas lahan kebun yang sempit, juga berbatu-batu, bahkan memiliki kemiringan lereng yang terjal (seperti bagian atas kaki lereng Gunung Ar dari ohoi Wasar menuju Haar (bekas Kampung Raja dahulu). Manajemen atau pengelolaan lahannya secara teknis dilakukan dengan mengandalkan modal alami, serta berbasis tebas-bakar-tanam sesuai kondisi iklim.

Semua keunikan lokal-setempat cenderung terabaikan/termarginalkan dalam pengetahuan ilmu tanah moderenuniversal yang homogen dan top-down serta pembangunan pertanian rakyat selama ini. Hal ini berdampak negatif terhadap pembangunan ohoi/desa adat yang memberdayakan dan memandirikan. Kecuali memadukan ilmu tanah moderen (khusus evaluasi kesesuaian lahan seperti sistem Food and Agricultural Organization - FAO), kearifan lokal (pengetahuan tradisional) tentang sumber daya tanah dan lahan setempat yang digali (diinventarisasi) melalui surveypemetaan transek dan evaluasi lahan partisipatif yang adaptif (Cools et al., 2003; Ufie, 2004; Goma et al., 2001; Hiwasaki et al., 2014; Rayes, 2007; Djaenudin et al., 2000; FAO, 1994; Undang-undang No.27 tahun 2007; Undangundang No.6 Tahun 2014; Peraturan Pemerintah RI Nomor 43 Tahun 2014). Hal ini sejalan dengan pendapat para ilmuwan yang menekuni pengelolaan lingkungan pulau-pulau kecil (Dahl, 1998; Monk et al., 2000), termasuk Esomar dan Ufie (2008) mengemukakan bahwa begitu banyak pendekatan pembangunan pulau kecil yang diimport mentahmentah (termasuk ilmu pengetahuan dan teknologi) yang lalu terbukti merusak sumberdaya, bersama teknik-teknik tradisional yang telah beradaptasi dengan kondisi-kondisi lokal dan beradab selama berabad-abad, yang dapat merupakan petunjuk yang baik bagi pembangunan berkelanjutan. Dalam bukunya berjudul 'Small Island Environmental Management', Dahl (1998) menandaskan bahwa salah satu tragedi terbesar pada kebanyakan masyarakat pulau-pulau kecil (seperti halnya kepulauan Kei dan Maluku pada umumnya) dewasa ini, adalah begitu banyak budaya tradisional/lokal dan pengetahuan lingkungan arif yang semakin hilang.

Sejauh ini, baru ada penelitian Survei LTA-72 (1986) berskala tinjau 1:250.000 pada akhir tahun 1985 untuk Kepulauan Kei khusus inventarisasi 'data fisik lahan', yang mencakup wilayah Wasar seputar lahan pesisir kaki Gunung Ar (puncaknya di bagian belakang 7000 kaki $2.134 \mathrm{~m}$ di atas permukaan laut) dengan pendekatan moderen dan belum bersifat rinci/detail. Karenanya dipilih untuk diteliti pada penelitian ini dengan topic 'Integrasi kearifan lokal dalam evaluasi lahan bagi budidaya enbal pada kaki Gunung Ar, Pulau Yut, Maluku Tenggara, Provinsi Maluku’.

\section{BAHAN DAN MOTODE}

\section{Waktu dan Tempat}

Penelitian ini dilaksanakan pada Ohoi Wasar (lahan pesisir pada kaki Gunung Ar), Kecamatan Kei Besar Utara Timur, Kabupaten Maluku Tenggara, pada bulan Maret 2018 sampai April 2018. 


\section{Bahan dan Alat}

Bahan dan alat yang digunakan dalam penelitian ini adalah: akuades, larutan $\mathrm{H}_{2} \mathrm{O}_{2}, \mathrm{HCl}$, kertas pH peta situasi, GPS, kamera, bor, kompas, altimeter, abney level, soil munssel color chart, kartu deskripsi, meter roll, pisau lapang, parang, pacul, alat perekam, tulis menulis, dan kuisioner semi-terstruktur.

\section{Pelaksanaan Penelitian}

Metode yang digunakan dalam penelitian ini adalah metode survei berbasis transek secara partisipatif berorientasi tujuan, yang difokuskan pada petani yang bercocok tanam ubi kayu (enbal). Pendekatan yang digunakan adalah wawancara (rujukan kuesioner) secara terfokus dengan petani pemilik kebun yang telah turun-temurun mengusahakan tanaman ubi kayu (enbal), pada lahan pesisir kaki Gunung Ar, Ohoi Wasar. Para pemilik kebun enbal dijadikan orang kunci, selain beberapa tokoh desa yang relevan, di dalam pembelajaran bersama (pertukaran pengetahuan) secara partisipatif-dialogal, tentang antara lain: bagaimana proses menentukan lokasi tanah/lahan yang baik (sangat cocok/sesuai) untuk kebun enbal, tanah yang kurang/tidak sesuai untuk enbal secara etnopedologi, musim buka kebun (juga dikenal dengan istilah 'penyiapan lahan') dan waktu tanam. Ini diikuti dengan pendekatan sains dalam melakukan identifikasi/pengamatan karakteristik relevan (boring dan profil) pada tanah-tanah yang dinilai paling cocok dan sedang-tidak sesuai menurut pengetahuan/kearifan lokal bagi usaha kebun enbal. Ini meliputi karakteristik tanah dan lereng, ketinggian yang diidentifikasikan/diamati ditambah dengan data iklim dari stasiun iklim terdekat di Hollat. Selanjutnya, data dibandingkan dengan tabel kesesuaian lahan Ubi Kayu dalam menentukan peringkat/kelas kesesuaian sesuai prosedur evaluasi lahan FAO \& Kriteria Kesesuaian Lahan dari Djaenudin et al. (2020).

\section{Tahap-tahap Pelaksanaan}

Pekerjaan persiapan. Pekerjaaan persiapan meliputi pengumpulan data sekunder tentang daerah penelitian, mempersiapkan alat dan bahan yang digunakan, administrasi perjalanan dan kebutuhan lainnya.

Pekerjaan lapangan. Pekerjaan lapangan dilakukan berbasis transek secara partisipatif yang dibuat fleksibel berorientasi tujuan, dimana peneliti bersama-sama dengan pemilik kebun enbal mengunjungi areal kebun mereka pada jalur transek. Pertanyaan kunci (kuesioner semi-terstruktur) yang perlu ditelaah dari masyarakat adalah bagaimana mereka menentukan tanah/lahan yang paling sesuai/cocok-cukup sesuai-dan tidak sesuai (secara etnopedologi Wasar) untuk dijadikan kebun enbal. Selanjutnya digali informasi bagaimana mereka menentukan musim buka kebun serta waktu tanam enbal. Pembelajaran bersama masyarakat adalah bagaimana mereka menentukan semua indikator lokal yang berhubungan dengan kebutuhan tanaman enbal. Dilakukan pencatatan indikator ilmiah melalui pengamatan identifikasi/boring dan profil pada tanah/lahan yang dinilai paling sesuai - cukup sesuai - tidak sesuai untuk usaha kebun enbal menurut pengetahuan/kearifan local. Beberapa karakteristik relevan yang diamati adalah kedalaman, warna, tekstur, $\mathrm{pH}$, dan lain-lain. Lokasi pengamatan diindikasikan pada peta situasi dan transek.

\section{Pengolahan Data}

Data tanah/lahan maupun musim yang diinventarisasi dari pengetahuan/keraifan lokal-tradisional dan pengetahuan moderen (ilmu tanah khusus evaluasi lahan sistem FAO \& Tabel Kriteria Kesesuaian Lahan untuk komoditas pertanian khususnya enbal dari Djaenudin et al. (2020) diolah dalam menentukan kesesuaian/kecocokannya bagi budidaya tanaman enbal di Ohoi Haar-Wasar. Selanjutnya dilakukan analisis hubungan kesesuaian lahan dari keduannya, jika diintegrasikan/dikawinkan, yakni apakah berbeda atau sama hasilnya; kalau sama selanjutnya dijelaskan ketemunya dimana dan mengapa demikian.

\section{HASIL DAN PEMBAHASAN}

\section{Gambaran Umum Lokasi Penelitian}

\section{Letak lokasi di lahan Desa/Ohoi Wasar dan batas Ohoi}

Lokasi penelitian berada pada kaki Gunung Ar (kurang lebih $300 \mathrm{~m}$ di atas permukaan laut), merupakan lahan pesisir, termasuk wilayah Desa/Ohoi Wasar, di Pulau Yut atau Kei Besar Utara Timur. Batas wilayah/petuanan dari Ohoi Wasar ini adalah sebagai berikut: sebelah Timur berbatasan dengan laut (Arafuru), sebelah Barat dengan Ohoi Ad, sebelah Utara dengan Kabalus (Haar bekas Kampung Raja), dan sebelah Selatan berbatasan dengan Desa Ur (Gambar $1)$.

\section{Iklim/musim, transportasi laut dan aktifitas kebun dan melaut tahunan}

Iklim khususnya musim/cuaca lokal setempat sangat penting diperhatikan/diperhitungkan oleh masyarakat Ohoi Wasar, bahkan semua masyarakat Desa di Pesisir Pulau Kei Besar Utara Timur secara umum. Hal ini menjadi keunikan dan kerumitan tersendiri. 
Menurut pengetahuan lokal masyarakat Ohoi Wasar tentang dinamika musim tahunan (salah satu jenis kearifan lokal setempat), biasanya musim teduh bagi transportasi laut di Kei Besar Utara Timur (angin ombak minim) adalah bulan Desember sampai April (pertengahan). Pada bulan Maret (akhir) mulai berembus angina pancaroba (musim peralihan) dengan sedikit angin-ombak dan guntur hebat, berbarengan dengan panen "laor/es' $u$ " (orang kei menyebutnya "enyaduk es'u = laor) di laut, dan panen "boo" di darat (mirip ubi putih atau Discorea hispida). Sambil memanen "boo" yang tumbuh secara alami untuk dikonsumsi bersama "es' $u$ " selama satu atau dua bulan, aktivitas penyiapan kebun dan penanaman enbal segera dimulai pada akhir April sampai awal bulan Mei. Perhitungan penyiapan lahan kebun/tebas dan bakar dilakukan tepat sebelum mulai musim hujan, sebab jika terlambat maka pembakaran bahan organik tebasan tidak sempurna/tuntas akibat ditimpa hujan (istilahnya "looryafmat" menurut orang Wasar, yang artinya terlambat bakar/tanam), dengan konsekuensi gagal panen.

Hasil perhitungan Neraca Air yang dibuat oleh LTA-72 (1986) berdasarkan data stasiun Hollat yang dekat dengan Ohou Wasar menunjukkan bahwa salah satu puncak hujan berkisar antara bulan April dan Mei.

\section{Geologi dan Geomorfologi/Lansekap}

Secara geologi, menurut LTA-72 (1986) kepulauan Kei berada pada suatu posisi busur depan/luar dimana bagian tepi atau ujung lempeng litosfer Kontinen Australia (Dangkalan Sahul = Sahulland), mengalami subduksi atau tubrukan/tunjaman dengan Busur Banda. Khususnya pulau Yut atau Kei Besar (termasuk Gunung Ar di bagian Utara Timur ke arah dalam) pada zaman es pleistosin. Akibat dari gerakan-gerakan tersebut lekungan-lekungan (yang menurun dan menaik) dari batuan-batuan dasar yang lasimnya lunak (batuan sedimen biasa), cenderung mengeras (seperti batu papan) berlawanan ke arah $60^{\circ}$ dengan bidang-bidang patahan. Batu-batuan yang muncul membentuk Kei Besar adalah lebih tua dan keras (limestone rock) dari karang koral dan kalkarenit di pulau Kei Kecil.

\section{Kondisi Tanah Menurut Pengetahuan Moderen, Hutan dan Hidrologi}

Gambaran Kondisi tanah meurut pengetahuan moderen (pedology, soil science) yang dikemukakan disini, dikutip dari hasil penelitian LTA-72 (1986) dengan lokasi yang berdekatan dengan lokasi penelitian.

a. Untuk profil tanah yang dibuat di lokasi Ohoiraut dengan landform yang curam sampai sangat curam (55\%) dan sekelilingnya bergunung/pegunungan, land use kebun pertanian tua/tradisional. Kategori jenis tanah menurut TOR (Indonesia): Lithosol/Rensina; FAO: Lithosol/Rensina; USDA (US Department of Agriculture): Lithic Ustorthent/Litchic Haplustoll.

b. Sedangkan profil tanah kedua yang dibuat pada lokasi Haar-Ohoiwait, dengan landform berlereng cekung (6\%) dan sekelilingnya berombak (undulating), land-use kebun pertanian tua/tradisional (kopi, kelapa, kenari, sukun, pisang, enbal, papaya). Kategori jenis tanah menurut TOR (Indonesia): Lithosol; FAO: Lithosol; USDA: Lithic Ustorthent.

\section{Temuan dan Implikasi Penelitian}

\section{Pengadaptasian metode}

Penelitian integrasi kearifan lokal dalam evaluasi lahan Sistem FAO bagi budidaya tanaman enbal pada lahan pesisir seputar kaki Gunung Ar, Ohoi Wasar ini dilaksanakan dengan metode survey berbasis transek secara parsitipatif berorientasi tujuan, dan difokuskan pada petani-petani yang berkebun atau bercocok tanam enbal (ubi kayu). Dari segi pengetahuan tanah moderen (soil science atau pedologi), identifikasi/pengamatan karakteristik tanah relevan dilakukan, melalui pembuatan boring dan profil pada jalur transek yang dibuat melewati kebun enbal para petani.

Dalam pelaksanaan di lapangan tahap pertama diadakan diskusi partisipatif-dialogal secara umum dengan para petani kebun enbal di rumah kepala Ohoi Wasar, yang dipandu oleh Sekertaris Ohoi dan para peneliti berbicara sebagai fasilitator utama dalam menyampaikan tujuan penelitian dan memerlukan bantuan partisipatif dari para petani responden sampel yang punya kebun enbal guna bercerita/sharing informasi yang berupa pengetahuan lokal orang Wasar dan kebiasaan-kebiasaan arif yang dipraktekan sejak leluhur terkait usaha kebun enbal, seperti bagaimana menentukan lokasi/lahan yang baik/cocok, penentuan waktu buka kebun (tebas-bakar) dan tanam, bagaimana mengenal karakteristik tanah secara tradisional dan lain-lain.

Sekaligus diskusi ini memberi kesempatan kepada para pemilik kebun enbal untuk memberi masukan/usulan dalam diskusi/sharing umum ini, di mana mereka secara spontan mengusulkan dua lokasi kebun (sekaligus dijadikan dua jalur transek), dan membagi diri dalam dua kelompok sesuai lokasi kebun guna membantu men-sharing kearifan pengetahuan lokal-tradisional yang dimiliki secara spesifik dan mendalam pada kebun masing-masing, dalam dua hari bersama sekertaris Ohoi Wasar selaku pemandu. Selain itu, diskusi dan pembelajaran bersama terus dilakukan, baik di kampung maupun setelah peneliti kembali ke Ambon (melalui media informasi digital). Hasil penelitian partisipatif yang dilakukan dapat divisualisasikan secara skematis dalam dua jalur transek (Gambar 2). 


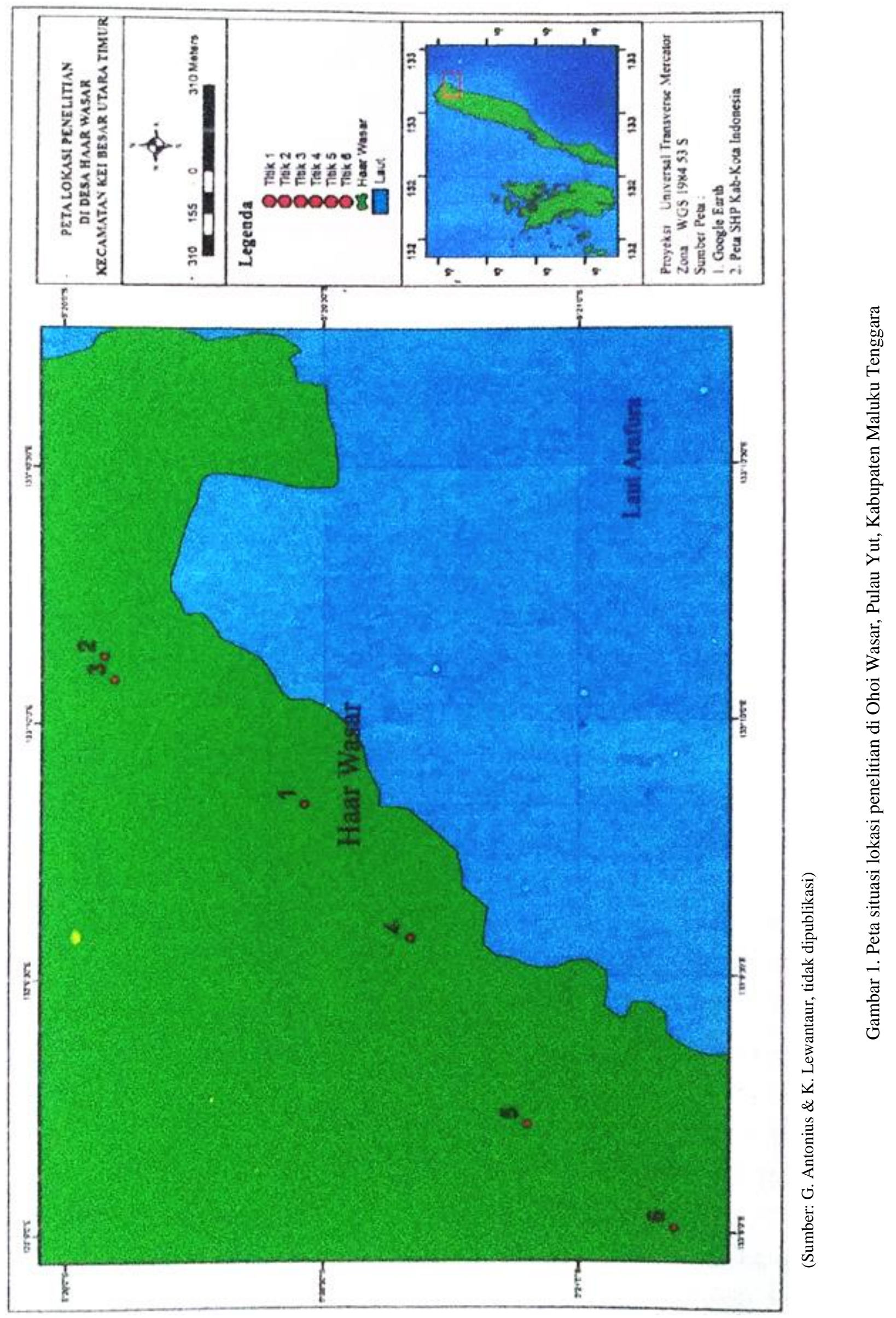


Tabel 1. Karakteristik iklim (curah hujan, temperature, bulan-kering) di Ohoi Wasar

\begin{tabular}{|c|c|c|c|c|c|c|c|c|c|c|c|c|c|}
\hline Karakteristik iklim & Jan & Feb & Mar & Apr & Mei & Jun & Jul & $\mathrm{Agu}$ & Sep & Okt & Nov & Des & Tahunan \\
\hline $\begin{array}{l}\text { Curah hujan } \\
\text { Rataan curah Hujan (mm/bulan) }\end{array}$ & 554 & 454 & 489 & 394 & 602 & 406 & 290 & 100 & 101 & 97 & 167 & 295 & 3949 \\
\hline $\begin{array}{l}\text { Rataan curah hujan (hari) } \\
\text { Temperature }\end{array}$ & 24,7 & 20.5 & 13.2 & 19.3 & 24.9 & 19.7 & 17.7 & 10.3 & 10.5 & 9.0 & 13.3 & 15.0 & 16.5 \\
\hline Rataan temperature bulanan $\left({ }^{\circ} \mathrm{C}\right)$ & 26,2 & 25,9 & 26.5 & 26,8 & 26,3 & 25,8 & 25,1 & 25,9 & 25.9 & 27.1 & 28.0 & 27.1 & 26.4 \\
\hline Evaprotranspirasi & 128 & 123 & 133 & 139 & 130 & 121 & 109 & 121 & 123 & 145 & 163 & 145 & 1570 \\
\hline
\end{tabular}

Sumber: LTA-72 (1986)

\section{Kearifan Lokal Masyarakat Ohoi Wasar dalam Pengelolaan Lahan Pesisir bagi Budidaya Tanaman}

\section{Enbal (Sistem Etnopedologi)}

\section{Penentuan tanah/lahan yang cocok atau sesuai bagi usaha kebun enbal}

Sebagai gambaran umum tentang kearifan lokal-tradisional dari orang Wasar dalam penetuan tanah/lahan yang cocok atau sesuai bagi usaha kebun enbal pada kaki Gunung Ar, disajikan ilustrasi lapangannya secara skematis dalam dua transek (transek pertama, transek kedua). Dari ilustrasi distribusi tanah pada transek pertama dan transek kedua (Gambar 2) tersebut nampak bahwa kondisi karakteristik tanah tidak bermasalah terutama dalam soal kedalaman dan hamparan batuan permukaan. Kalaupun tanahnya kebanyakan dangkal dan berbatu dapat disiasati untuk memperbaiki produktivitas enbalnya dengan "abu bakaran dalam pembentukan umbi" sebagai bagian dari kearifan pengetahuan lokal-tradisional yang dipraktekan lama sejak leluhur.

Selain kedalaman/kedangkalan tanah dan hamparan batuan, karakteristik tanah yang menjadi pengenal cocok/sesuai atau tidaknya tanah untuk usaha kebun enbal di Wasar, dapat teridentifikasi secara umum dari nama-nama tanah menurut pengetahuan lokal-tradisional setempat sebagai suatu bentuk kearifan yang khas. Hal ini dapat terungkap dari nama lokal pada transek pertama yang umumnya diberi nama "hadoirchr vuil" (tanah merah) atau "tanat vutun", menurut pengetahuan tradisional Orang Wasar, dibandingkan dengan nama tanah lokal pada transek kedua yang umumnya diberi nama lokal "hadoichr ngametan" (tanah hitam) dan "tanat warain" (tanah "atuvun"/hutan) berwarna hitam yang lebih subur. Sedangkan tanah yang tidak bagus/sesuai untuk kebun enbal, seperti P1 pada transek kedua yang bernama lokal "tanat meen/bah" (tanah liat coklat kuning abu-abu/kelabu yang lembab/berair dan ditumbuhi sagusagu tipe agroforesti). Bersama-sama dengan tanah kapur (limestone) pada lereng bawah $\mathrm{B}_{5}$ kurang lebih $150-200 \mathrm{~m}$ yang diberi nama lokal "tanat sisiat atau tanat rohat".

\section{Penentuan musim/hari buka kebun enbal (tebas-bakar) dan waktu tanam}

Telah dikemukakan bahwa kearifan pengetahuan lokal-tradisional Orang Wasar dalam penentuan kesesuaian tanah/lahan pesisir di kaki Gunung Ar bagi pengelolaan /budidaya kebun enbal tidak semata-mata dari karakteristik tanah yang cocok atau sesuai (seperti kedalaman/kedangkalan tanah dan hamparan batuan), tetapi yang juga penting adalah banyaknya abu bakaran dalam pembentukan umbi dan curah hujan, yang terkait erat dengan perhitungan musim/cuaca harian secara tepat. Jadi, penentuan lahan yang cocok/sesuai bagi usaha kebun enbal berdasarkan kearifan pengetahuan lokal Orang Wasar adalah berdasarkan kondisi tanah dan musim/cuaca harian bagi tebas-bakar-tanam (penyiapan lahan) secara bersamaan dan tidak dinilai terpisah.

Musim pancaroba/peralihan di daerah tersebut biasanya ditandai dengan sedikit angin ombak dan guntur lebat. Untuk musim penyiapan lahan kebun (tebas-bakar) dan penanaman enbal sebelum datangnya hujan pertama di awal tahun atau sampai pertengahan Mei tiap tahun, adalah sangat berisiko jika dikaitkan dalam menentukan tinggi/rendahnya produksi enbal per pohon. Produktivitas enbal terkait dengan tersedianya abu bakaran /pembakaran bahan organik tebasan, selain dari peran air dari "distribusi curah hujan" (bukan rataan curah hujan bulanan atau tahunan) untuk pertanian lahan kering termasuk dalam budidaya enbal seperti di Ohoi Wasar.

\section{Kesesuaian Lahan Bagi Usaha Kebun Enbal Menurut Sistem FAO}

Penentuan kesesuaian lahan menurut FAO untuk usaha kebun enbal ini adalah berdasarkan berbagai penghambat fisik (iklim, tanah, topografi) yang membatasi pertumbuhan tanaman yang diusahakan. Karakteristik iklim di lokasi penelitian tertera pada Tabel 1 .

Berdasarkan gambaran rataan curah hujan dan rataan temperatur tahunan dari stasiun iklim Hollat yang terdekat dengan lokasi penelitian, dibadingkan dengan kriteria kesesuaian lahan untuk Enbal secara formal (Djaenudin et al., 2000), maka baik curah hujan maupun temperature dinyatakan sangat sesuai $\left(S_{1}\right)$ menurut sistem FAO.

\section{Karakteristik tanah (tekstur, kedalaman, pH, $\left.\mathrm{H}_{2} \mathbf{0}\right)$}

Tiga karakteristik yang ditelaah disini adalah sesuai dengan persyaratan kesesuaian dalam Djaenudin et al. (2000). Untuk karakteristik tanah, kedalaman, dan batuan permukaan dapat dilihat pada kedua transek sedangkan untuk 
pH $\mathrm{H}_{2} \mathrm{O}$ diperoleh gambarannya dari hasil analisis LTA-72 khusus dua lokasi, yaitu Haar Ohoiwait dan Ohoiraut. Jika karakteristik Tanah yang dikemukakan dihubungkan dengan nama tanah menurut klasifikasi FAO, maka tanah-tanah pada transek pertama diklasifikasikan sebagai "Kambisol Distrik" (kurang lebih sama dengan menurut Orang Wasar). Sedangkan tanah-tanah pada transek kedua diklasifikasikan sebagai "Kambisol Eutrik" (mirip dengan nama lokal Wasar).

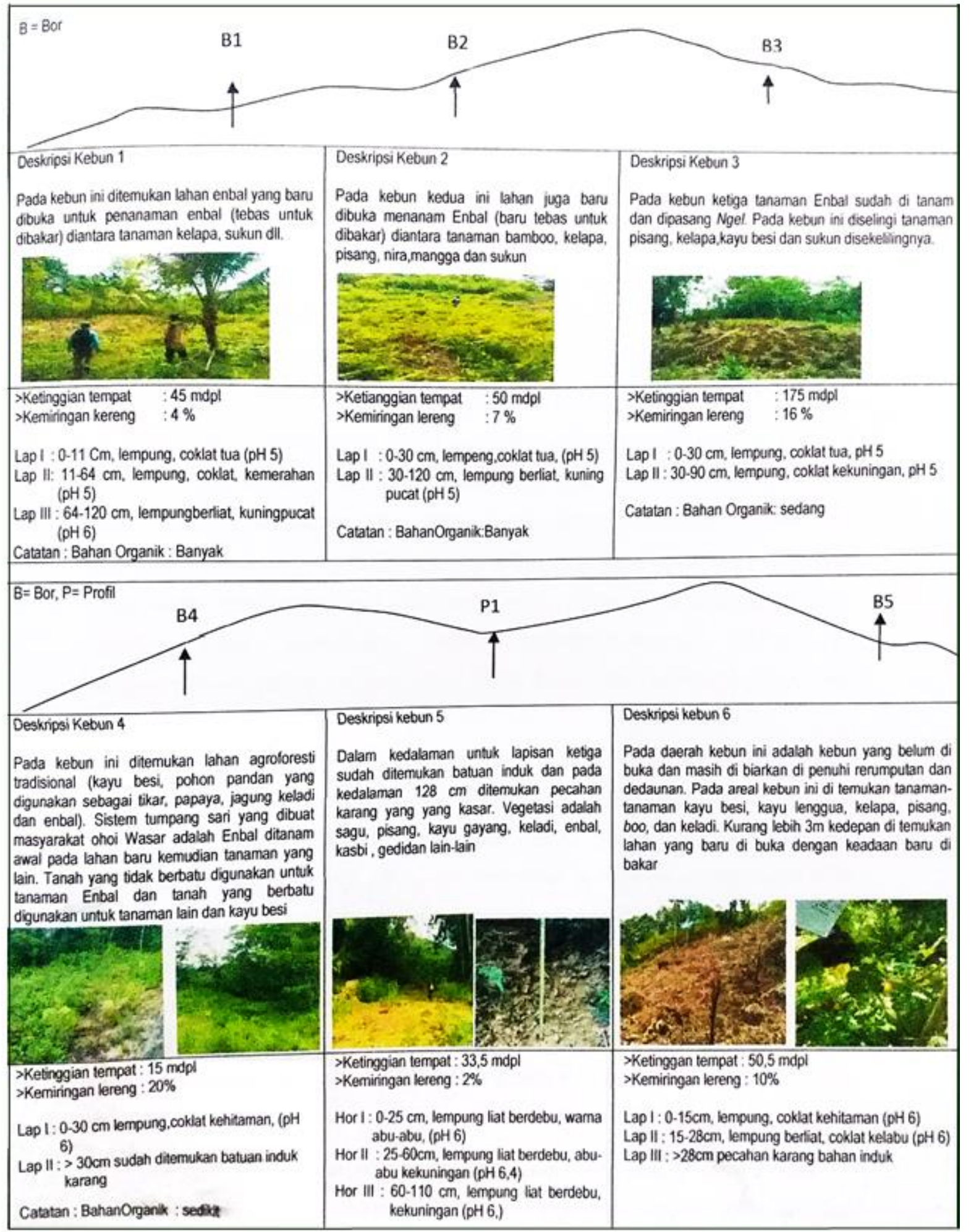

(Sumber: G. Antonius dan D. Torimtubun, tidak dipublikasi)

Gambar 2. Dua transek dengan kebun-kebun beserta deskripsi kondisi lahan, vegetasi dan tanahnya 


\section{Penyiapan lahan/kebun (batuan permukaan)}

Berdasarkan data lapangan yang dikemukakan, secara umum dapat dikatakan bahwa hanya sedikit tanah pada transek kedua yang "batuan permukaanya" 5-15\% (walaupun tidak ditulis) dan peringkat kesesuaian lahannya menurut kriteria pada Tabel 1 "cukup sesuai"; walaupun pada kenyataanya dilapangan menunjukan kondisi "batuan permukaan 5-15\%. Hal ini tidak bermasalah atau tidak merupakan pembatas karena aktifitas "penyiapan lahan atau kebun" mulai dari tebas/pamiri dan bakar sampai tanam tidak menggunakan mesin (hand tractor misalnya secara mekanis) tetapi menggunakan parang-pacul-piquel-linggis atau tugal secara tradisional. Sehingga dari segi "batuan permukaan" untuk penyiapan lahan kebun secara tradisional tidakl bermasalah (dianggap kelasnya $\mathrm{S}_{1}$ ).

\section{Hubungan Kesesuaian Lahan Menurut Kearifan Pengetahuan Tanah Lokal/Tradisional (Sistem Etnopedologi) dan Sistem FAO}

Dalam penilaian kesesuaian/kecocokan lahan yang menghubungkan secara integratif pendekatan kearifan pengetahuan tanah lokal-tradisional dengan pendekatan pengetahuan moderen evaluasi lahan, tidak semua karakteristik lahan (Tabel 1 menurut FAO) dikaji, tetapi dibatasi pada tiga karakteristik (iklim, tanah, penyiapan lahan).

\section{Perbedaan dan kesamaan dalam penentuan kesesuaian lahan}

Secara praktis, kearifan pengetahuan tanah lokal masyarakat adat Wasar menyatakan bahwa tanah hitam (hadoichr ngametan) lebih subur atau cocok/sesuai untuk usaha budidaya/kebun enbal, kemudian diikuti tanah merah (hadoichr vuil). Sedangkan dari segi cuaca atau musim, khusus untuk "kebun musim timur" maka bulan/hari yang cocok untuk buka kebun atau penyiapan lahan (tebas-bakar-tanam) adalah akhir April sampai awal Mei.

Penentuan evaluasi lahan dengan pengetahuan moderen (FAO) berbeda, yaitu dimulai dengan evaluasi karakteristik iklim barulah karakteristik tanah (Tabel 1). Begitu pula dengan penelaahan kesesuaian tanah berdasarkan tiga karakteristik (Tabel 1), yaitu tekstur, kedalaman tanah dan $\mathrm{pH}$. Kesesuaian tanah dikelompokan ke dalam tiga kelas, yaitu: cukup sesuai (tanah-tanah dari transek pertama, Gambar 2), sangat sesuai (tanah berprofil P1 dari transek kedua) dan tanah dinyatakan tidak sesuai pada transek kedua (B4,B5). Penelaahan karakteristik "penyiapan lahan" berdasarkan atas kondisi batuan permukaan untuk sistem FAO, untuk budidaya pertanian tradisional non-mekanis juga berbeda, karena Orang Wasar lebih berbasis pada perhitungan cuaca/musim.

Kesamaannya dalam penentuan kesesuaian lahan untuk kedua sistem (sistem etnopedologi dan sistem FAO) kelihatan terbatas pada telaah kesuburan tanah yang dinyatakan sebagai lebih subur/cocok menurut orang Wasar adalah hadoichr ngametan atau tanah hitam (seperti pada transek kedua), berikutnya hadoichr vuil atau tanah merah (transek pertama). Di sisi lain, dengan penentuan keseuaian lahan berbasis kesuburan indikator $\mathrm{pH}$ (retensi unsur hara) menurut sistem FAO, tanah hadoichr ngametan kurang lebih sama dengan Kambisol Eutrik yang pH-nya $\geq 6$ dan dinyatakan sebagai "sangat sesuai $\left(\mathrm{S}_{1}\right)$ " untuk tanaman enbal; berikutnya hadoichr vuil yang kurang lebih sama dengan Kambisol Distrik yang pH-nya $\leq 5$ dan termasuk "cukup sesuai $\left(\mathrm{S}_{2}\right)$ ". Dengan demikian, penentuan kesesuaian untuk kedua sistem ketemunya/titik temunya di sini.

\section{Kesamaan atau titik temu dalam penentuan kesesuaian lahan secara terintegrasi}

Kajian integrasi kearifan lokal dalam evaluasi lahan moderen FAO bagi budidaya tanaman enbal pada kaki Gunung Ar, Ohoi Wasar di Pulau Yut atau Kei Besar Utara Timur ini merupakan bagian dari upaya mengadaptasi/membumikan pengetahuan moderen-universal tersebut agar benar-benar relevan dan adaptif dengan kondisi lokal. Demikian halnya dengan hubungan nilai pH-kadar kalium (K) dan abu bakaran, dapat diperluas juga dengan ketepatan pehitungan cuaca untuk penyiapan lahan ('kebun musim timur') dalam rangka meningkatkan produksi /industri enbal rakyat Ohoi Wasar yang berkelanjutan dan mandiri.

\section{KESIMPULAN}

Kesimpulan-kesimpulan dari penelitian ini adalah sebagai berikut:

1. Terdapat dua kearifam lokal-tradisional (sistem etnopedologi) yang ditemukan dan satu kearifan lokal pendukung di Ohoi Wasar, yaitu pertama, kearifan penentuan tanah/lahan yang cocok atau sesuai bagi usaha kebun enbal yang disebut hadoichr ngametan (tanah hitam) dan hadoichr vuil (tanah merah), dan kedua, kearifan penentuan waktu/hari buka kebun enbal (tebas-bakar) dan waktu tanam.

2. Kesesuaian lahan bagi usaha kebun enbal menurut sistem FAO, fokus tinjauannya cenderung dibatasi pada karakteristik iklim, tanah dan penyiapan lahan.

3. Hubungan kesesuaian lahan jika pendekatan kearifan pengetahuan tanah lokal-tradisional (etnopedologi) diintegrasikan dalam/dengan evaluasi lahan FAO, titik temunya (overlap) adalah pada telaahan kesuburan tanah, yakni bahwa keduanya mengkategorikan "tanah hitam = Renzina" dengan pH 6 sebagai yang lebih subur/cocok (sangat sesuai) untuk tanaman enbal, sedangkan "tanah merah" = Kambisol Distrik dengan pH 5 atau kurang sebagai tanah yang agak subur/cocok (cukup sesusai). 


\section{DAFTAR PUSTAKA}

Bulbeck, D. 2006. The Last Glacial Maximum Human Burial from Liang Lemdubu in Northern Sahulland. In O'Connor, S., Spriggs and P. Veth (Eds), The Archeology of the Aru Islands, Eastern Indonesia (Terra Australis Vol. 22). ANU E-Press, Canberra. ISBN/ISSN: 9781921313042.

Clarke, W.C. and R.R. Thaman. 1993. Agroforestry in the Pacific Islands: System for Sustainability. UN University Press, Tokyo. ISBN 92-808-0824-9.

Cools, N., E. De Pauw, and J. Deckers. 2003. Towards an integration of conventional land evaluation methods and farmers soil suitability assessment: a case study in North Western Syria. Agriculture, Ecosystems and Environment 95:327-342. DOI: 10.1016/S0167-8809(02)00045-2.

Dahl, A.L. 1988. Small Island Environmental Management: Training Programme. Prepared For the South Pacific Regional Environmental Programme. Unep Earthwactch: Geneva, Switzerland.

Djaenudin, D., H. Marwan, A. Subagyo, Mulyani, dan N. Suharta. 2000. Kriteria Kesesuaian Lahan Untuk Komoditas Pertanian. Versi 3.0. Puslitanah, Badan Litbang Pertanian, Bogor

Esomar, J. dan C. Ufie. 2008. Prosiding Seminar dan Lokakarya Tentang Pengetahuan Tradisional Dalam Menajemen Hutan Berkelanjutan untuk Penyediaan Air di Pulau Kei Kecil. Proyek NFP-FAO. Badan Penerbit Fakultas Pertanian Universitas Pattimura (BPFP-Unpatti), Ambon.

FAO. 1976. A Framework for Land Evaluation. Soil Bulletin Number 32. FAO, Rome.

FAO. 1994. The Role of Agriculture, Forestry and Fisheries in The Sustainable Development of Small Island Development States. FAO, Rome. DOI: 10.1016/S0167-8809(01)00277-8

Hiwasaki, L., E. Luna, Syamsidik and R. Shawd. 2014. Process for integrating local and indigenous knowledge with science for hydro-meteorological disaster risk reduction and climate change adaptation in coastal and small island communities. International Journal of Disaster Risk Reduction 10(A): 15-27. DOI: https://doi.org/10.1016/j.ijdrr.2014.07.007.

LTA-72, 1986. Kei Island Development Study Volume 1: Basic Data Report for Land Evaluation. Maluku Regional Planning and Development Project, LTA-72- Unpatti, Ambon.

Monk, K.A., Y. De Fretes, and G. Reksodihardjo-Lilley. 2000. Ekologi Nusa Tenggara dan Maluku. Prehallindo, Jakarta. ISBN: 979-683-027-2.

Prihandana, R., K. Noerwijati, P. Gamawati, Adinurani, D. Setyaningsih, S. Setiadi dan R. Handoko. 2007. Bioetanol Ubi Kayu: Bahan Bakar Masa Depan. AgroMedia Pustaka, Jakarta. ISBN: 979-006-131-5

Rayes, M.L. 2007. Metode Inventarisasi Sumber Daya Lahan. Yogyakarta: Andi. ISBN: 979-763-613-5.

Ufie, C. 2004. Urgensi kompetensi etnopedologi yang partisipatif mendukung rekonstruksi pertanian kepulauan dan ketahanan pangan Maluku pasca-konflik. Jurnal Pertanian Kepulauan 3(3): 74-79.

Undang-Undang RI Nomor 27 Tahun 2007 Tentang Pengelolaan Wilayah Pesisir dan Pulau-Pulau Kecil. 17 Juli 2007. https://www.dpr.go.id/dokjdih/document/uu/UU_2014_1.pdf

Undang-undang RI Nomor 6 Tahun 2014 Tentang Desa, 30 Mei 2014. https://www.dpr.go.id/dokjdih/document/uu/UU_2014_6.pdf

Peraturan Pemerintah RI Nomor 43 Tahun 2014 Tentang Peraturan Pelaksanaan UU RI No. 6/2014 Tentang Desa, 3 Juni 2014

Widodo, P., R. Susila, dan Wasmanudin. 2018. Analisis kesesuaian kahan agroforestry berbasis sistem informasi geografi (SIG) di Desa Sindulang, Kabupaten Sumedang. Wanamukti 21(2): 125-134. DOI: http://dx.doi.org/10.35138/wanamukti.v21i2.167

Yen, D.E. 1995. The development of Sahul agriculture with Australia as bystander. In J. Allen and J.F. O’Connell (Eds.), Transitions: Pleistocene to Holocene in Australia and Papua New Guinea, Antiquity 69, special number 265: 831-847. 